\title{
The Antecedents of Psychic Distance
}

\author{
Håkanson, Lars; Ambos, Björn
}

Document Version

Final published version

\section{Publication date:}

2008

\section{License \\ CC BY-NC-ND}

Citation for published version (APA):

Håkanson, L., \& Ambos, B. (2008). The Antecedents of Psychic Distance. Department of International

Economics and Management, Copenhagen Business School. Working Paper / Department of International Economics and Management, Copenhagen Business School No. 3-2008

Link to publication in CBS Research Portal

\section{General rights}

Copyright and moral rights for the publications made accessible in the public portal are retained by the authors and/or other copyright owners and it is a condition of accessing publications that users recognise and abide by the legal requirements associated with these rights.

\section{Take down policy}

If you believe that this document breaches copyright please contact us (research.lib@cbs.dk) providing details, and we will remove access to the work immediately and investigate your claim. 


\title{
The Antecedents of Psychic Distance
}

\author{
Lars Håkanson ${ }^{1}$, Björn Ambos ${ }^{2}$ \\ ${ }^{1}$ Department of International Economics and Management, Copenhagen Business School, \\ Porcelain Garden/Porcelcenshaven 24, DK-2000 Frederiksberg, Denmark \\ Email: 1h.int@cbs.dk Phone: +45 38152533 Fax:+45 38152500 \\ ${ }^{2}$ Institute for International Marketing and Management, Vienna University of Economics and Business Administration, \\ Augasse 2-6, A-1090 Vienna, Austria \\ Email: bjoern.ambos@wu-wien.ac.at Phone: +43 (1) 313365121 Fax: +43 (1) 31336776
}

\begin{abstract}
This study investigates the antecedents of psychic distance. Building on original data in 25 of the world's largest economies, we investigate potential drivers of the perceived distance among a given pair of countries. Results confirm that psychic distance is indeed a multifaceted construct which is determined by cultural, geographic and economic factors. Furthermore, our results indicate that geographic distance accounts for the largest share of the explained variance, suggesting that future studies should attribute geographic distance a more prominent role when it comes to empirically investigating international business decisions for which psychic distance perceptions may be important. They also suggest that, used in isolation, cultural distance as measured by the so called Kogut and Singh index - is a poor predictor of distance perceptions.
\end{abstract}

Keywords: Cultural Distance, Geographic Distance, Cross-Cultural Research/Measurement Issues, Psychic Distance

\section{ACKNOWLEDGEMENTS}

The authors gratefully acknowledge the help of the following researchers that helped in collecting the psychic distance data that constitutes the dependent measure in this study. Ulf Andersson (Uppsala University), Per Andersson (Stockholm School of Economics), Marian Beise (Kobe University), Paul Beamish (University of Western Ontario), Gabriel Benito (BI Norwegian School of Management), Alberto Bonisoli (Domus Academy), Nick Bontis (McMaster University), Paul Brewer (University of Queensland), Danny van der Bulcke (University of Antwerp), Stephan Buse (TU Hamburg), Malgorzata Bartosik-Purgat (Poznan University of Economics), Jean-Luc Cerdin ESSEC, Sigurd Eltvik (Stockholm School of Economics), Felicia Fai (University of Bath), Philip Gugler (University of Fribourg), Esra Genkturc (Koc University), Carlos Hemais (Federal University of Rio de Janeiro), Maria Henoch (Fudan University), Latyaeva (Kingston University Business School), Sang Lee (Hanyang University), Kiyoshi Miyashita (Tokyo Metropolitan University), Bo Nielsen (Copenhagen Business School), Pedro Nueno (IESE), Ki-an Park (Kyung Hee University), Krzysztof Obloj (University of Warsaw), Bino Pathiparampil (Indian Institute of Management) Murali Patibandla (Indian Institute of Management), Jacobo Ramirez (Tecnológico de Monterrey) Andreas Riege (Griffith University), Vicente Safon (University of Valencia), Arjen Slangen (Erasmus University), John Steen (University of Queensland), Koji Takahashi (Nanzan University), Emanuela Todeva (University of Surrey), Jan-Erik Vahlne (University of Gothenburg), Roberto Vassolo (Universidad Austral), Markus Venzin (Bocconi University), Gerhard Wuehrer (University of Linz), Burhan Yavas (California State University), Max von Zedtwitz (Tsinghua). 


\section{INTRODUCTION}

The concept of 'psychic distance' and its close relative 'cultural distance' have come to occupy central roles in international business (IB) research. Usually defined as the perceived difference between two countries, these concepts have been invoked to explain a wide range of international business phenomena, such as the choice of export markets and foreign entry modes (critically reviewed in Harzing, 2004), but including also, for example, the design of human resource management practices (Rosenzweig and Nohira, 1994; Björkman and Furu, 2000), the power of foreign distributors (Griffith and Harvey, 2001), negotiating tactics (Rao and Schmidt, 1998), the propensity to undertake R\&D in foreign subsidiaries (Muralidharan and Phatak, 1999) and the design of knowledge transfer practices (Simonin, 1999; Minbaeva et al. 2003). The general assertion in most of these studies is that the more different a foreign environment is as compared to that of a firm's (or an individual's) country of origin, the more difficult it will be to collect, analyze and correctly interpret information about it, and the higher are therefore the uncertainties and difficulties - both expected and actual - of doing business there.

However, these seemingly straightforward assertions have recently been called into question by an increasing empirical body of anomalous and partly contradictory findings. As a result scholars have started to point to a number of fundamental theoretical and methodological problems in the way that country differences have been conceptualized and operationally measured in the literature (Brewer, 2007; Harzing, 2004; Kirkman,Lowe and Gibson, 2006; Lu, 2006; Shenkar, 2001; Sousa and Bradley, 2004; Stöttinger and Schlegelmilch, 1998; Tihanyi, Griffith and Russell, 2005; Zhao, Luo and Suh, 2004). It has been pointed out, for example, that decision-makers may systematically underestimate 'real' differences to countries perceived to be very similar to the home country (O'Grady and Lane, 1996; Fenwick, Edwards and Buckley, 2003), that perceptions among two nations are not necessary symmetrical and that they may change both with experience and over time (Shenkar, 2001).

In view of these problems, this paper departs from conventional practice and - following a suggestion by Shenkar (2001: 529) - attempts to measure psychic distance perceptions directly as opposed to 
approximation through one or more variables. We empirically explore the pattern of cognitive perceptions of country distances in a unique data set comprising more than 1600 respondents in 25 countries, providing estimates of perceived 'psychic distance' between 600 country pairs. We use this procedure to tackle one fundamental, but surprisingly under-researched question: What are the drivers or antecedents of psychic distance perceptions? The objective is to determine the relative importance of possible antecedents - or 'psychic distance stimuli' (Dow and Karunaratna, 2006) - of such perceptions.

Given the centrality of the concept in IB research, the dearth of empirical evidence regarding which factors influence managers' perceptions of foreign countries is troublesome. There are often good theoretical grounds to assume that managerial perceptions of foreign countries have an influence on the phenomena studied in IB research. However, the almost total lack of knowledge regarding the formation and character of such perceptions make it near impossible to empirically analyze their characteristics and to construct valid and reliable measures for them.

In the two decades since it was originally suggested, it has become accepted practice in IB research to approximate psychic distance and other country differences with a single measure, the 'cultural distance' index proposed by Kogut and Singh (1988). Summarizing country differences in the cultural dimensions defined by Hofstede (1980), the Kogut and Singh index has become the paradigmatic operationalization of both 'psychic' and 'cultural' distance - often without any clear distinction between the two concepts (Kirkman et al., 2006). Lately, this practice has been the object of severe criticism (Dow, 2000; Dow and Karunaratna, 2006; Harzing, 2004; Kirkman et al., 2006; Shenkar, 2000; Zhao et al., 2004). Central to the critique have been (1) doubts as to whether 'cultural distance' as measured by the index is a valid and reliable proxy for managerial perceptions of psychic distance, and (2) the likely effect of such perceptions on managerial decision making in relation to other probable influences. The present paper addresses the first of these concerns. Previous criticisms have been based on theoretical considerations (Shenkar, 2000) and on the often 'unexpected' performance of the index' in statistical analyses (Kirkman, et al., 2008). But as Harzing (2004) has noted, only scarce empirical evidence has been available regarding the validity of the 
Kogut/Singh index as a proxy for managerial perceptions of psychic distance. This paper provides for the first time a comprehensive empirical analysis of the actual antecedents of such perceptions and their correlation with cultural distances as measured by the Hofstede dimensions. Our results show that the critique of the index appears well-founded and suggests how more valid and reliable measures might be constructed. ${ }^{1}$

The paper is organized as follows. The next section provides the starting point for the analysis. It compares alternative conceptualizations of country differences found in the literature, explicating the (often implicit) assumptions on which they are based and identifying the scope of their potential applications in IB theory and research. Drawing on this discussion, section 3 formulates a set of hypotheses regarding the antecedents of perceived psychic distance. Section 4 describes the methodology employed and provides a descriptive summary of the data. In section 5, the hypotheses are subjected to empirical testing, the implications of which are discussed in the final section, indicating conclusions regarding the theoretical properties of psychic distance and implications for the methodology of IB research, suggesting possibilities to improve the validity of measurements of country differences.

\section{THEORETICAL FOUNDATIONS}

\section{The Psychic Distance Concept}

In the original conceptualization - the one adopted in this paper - 'psychic distance' was defined as the subjectively perceived distance to a given foreign country ${ }^{2}$. This definition is not only consistent with the semantic origins of the term (from the Greek 'psychikos' = mind and soul), but is also in line with recent authors (Dow, 2000; Dow and Karunaratna, 2006; Holzmuller and Kasper, 1991; Sousa and Bradley, 2005, Stöttinger and Schlegelmilch, 1998), for whom 'psychic distance' refers to individuals' or collective's perceptions of foreign countries. The psychic distance to a specific foreign country is a reflection of the perceiver's knowledge, familiarity and sense of understanding of it (Dichtl et al, 1990; Dow and Karunaratna, 2006). 
Perceptual definitions of psychic distance recognize, at least implicitly, that individuals may differ in respect of their perceptions of foreign countries. Through family ties, for example, vacation habits, study leaves or other expatriate experiences, familiarity with and understanding of other countries are bound to differ between individuals (Dichtl et al, 1990). The significance of the concept for IB theory is that psychic distance, as perceived on average in a certain country - the measure in focus of this paper - may help explain the average behavior of firms from that country (Dow and Karunaratna, 2006).

\section{Origin and Evolution of the Psychic Distance Concept}

The concept of 'psychic distance' was introduced into the literature by Beckerman (1956), as an afterthought to a study on the impact of relative 'economic distance' on trade patterns, i.e. factors such as geographical distance, transportation costs and tariffs. In the last paragraph of his paper, he speculates on the role of 'psychic distance' for the observed tendency of countries to concentrate their trade on 'nearby' countries more strongly than economic distance alone could explain (interestingly from the importer's perspective rather than - as has become more common - that of the exporter):

... a special problem is posed by the existence of "psychic distance". It is probable that the manner in which the purchases of raw materials by a firm are distributed geographically will depend on the extent to which foreign sources have been personally contacted and cultivated. While the transport costs paid (directly or indirectly) by an Italian entrepreneur on a raw material supplied by Turkey may be no greater (as the material may come by sea) than the same material supplied by Switzerland, he is more likely to have contacts with Swiss suppliers, since Switzerland will be "nearer" to him in a psychic evaluation (fewer language difficulties, and so on), as well as in the economic sense that air travel will absorb less of his time. (Beckerman, 1956: 38)

'Psychic distance' was thus introduced as a subjective influence moderating the role of objective economic distance. ${ }^{3}$ The concept was picked up and introduced to the wider IB community by a group of scholars at Uppsala University, studying the choice of export markets and firm internationalization patterns (Hörnell, Vahlne and Wiedersheim-Paul, 1973; Johanson and Vahlne, 1977; Johanson and Wiedersheim-Paul, 1975). In the behavioral tradition of Simon (1947/1997), March and Simon (1958/1993), Cyert and March (1963) 
and Aharoni (1966), the group's lasting contribution was to enforce the idea that internationalization processes (and other international business transactions) are not only determined by objective economic realities but are influenced also by the availability of information and by the decision makers' cognitive capabilities.

Valuable as this contribution undoubtedly was, it introduced an ambiguity regarding the meaning of 'psychic distance' that has survived unto this date (Evans, Treadgold and Mavondo 2000a, 2000b; Sousa and Bradley, 2005a, 2005b). As the semantic origins of the term suggest, Beckerman's intention must surely have been to point out the importance of perceptions in the formation of foreign trade relationships. However, in the Uppsala School's original rendering of the concept, it meaning subtly changed. In the group's most influential contributions, 'psychic distance' was defined as "factors preventing or disturbing the flow of information between potential and actual suppliers and customers" (Vahlne and Wiedersheim-Paul, 1973). In line with this conceptualization, 'psychic distance' was operationally measured by three groups of statistical items: (1) characteristics of the target market, such as its level of development and the education of its workforce, (2) differences between Sweden and the target market in these factors, but also in regard of language and culture, and (3) trade relations (the relative level of imports), as an indication of established information channels. The objective was to complement the traditional emphasis on the costs of moving physical goods (transport costs, tariffs, etc.) with a measure intended to capture the cost of transferring the information necessary to effect such transactions. The subjective or behavioral component was introduced by explicitly recognizing that firms' abilities to deal with (or overcome) psychic distance differ, depending on, for example, their size and previous experience of foreign markets.

With the benefit of hindsight, this departure from the semantic roots of the concept must be considered to have been an important cause for the unfortunate ambiguity that has subsequently plagued the idea (Kirkman, et al., 2006; Shenkar, 2001). In the extant literature, 'psychic distance' is sometimes conceived of as a perceptual, subjective phenomenon, but more often as an objective, collective construct - an inconsistency that has been perpetuated over time. 
A further ambiguous aspect of the concept of 'psychic distance' is the degree of symmetry assumed or implied. By including among the determinants of psychic distance the characteristics of the target country, asymmetry is inherent in the Uppsala School's rendering of the concept - but only implicitly so. Both in the original studies and later, the question of symmetry never attracted a great deal of attention, probably because most studies involved the computation of psychic distances from a single focal country. However, as Shenkar (2001) has pointed out, there are good reasons to believe that psychic distances - in contrast to geographical distances and 'cultural distances' as conventionally measured - are not symmetrical, i.e. the perceived distances from A to B and from B to A are not necessarily equal. Indeed, as a number of studies confirm, measures of perceived distances based on respondents' judgments as to the degree of similarity between home and target countries produce asymmetry whenever more than one source country is involved (Brock, Shenkar, Shoham, and Siscovick, 2008; Dichtl et al., 1984, Ellis, 2008; Dow, 1990; Stöttinger and Schlegelmilch, 1998).

\section{Psychic Distance and Cultural Distance}

For the Uppsala School, cultural differences were only one aspect of psychic distance. However, in the latest two decades of IB research the distinction between 'psychic distance' and 'cultural distance' has become increasingly blurred. In apparent acceptance of Kogut and Singh's (1988:430) claim that “cultural distance is, in most respects, similar to the 'psychic distance' used by the Uppsala school”, the so-called Kogut and Singh index of 'cultural distance' has become the standard measure of both managers' ex ante perceptions of foreign countries prior to entry and the ex post ease or difficulty of operating in a foreign environment as well as a mediating influence for a range of other phenomena (Kirkman et al., 2006, Tihanya, et al., 2005, Zhao et al., 2004). But as pointed out by O'Grady and Lane (1996), managers' ex ante perceptions of psychic distance towards a foreign market may well differ from the actual distance, as experienced ex post an establishment there. Hence, perceptual measures appear to be more relevant than objective ones when it comes to analyses of foreign market selection, entry modes and the like. Objective measures may be more appropriate for studies of, for example, foreign subsidiary performance or expatriate turnover. 
The conceptualization of 'psychic distance' as the subjectively perceived distance between a home country and a given foreign one opens to questioning its operationalization as a formative construct, regardless of whether it is based on a range of different indicators (Hörnell et al., 1973; Brewer, 2007) or on a more narrow selection, such as in the Kogut and Singh (1988) 'cultural distance' index (Sousa and Bradley 2006). A theoretically and operationally more meaningful approach is to measure psychic distance directly and to subsequently enquire if and to what extent cultural distance, language differences and other factors impact these perceptions (Sousa and Bardley, 2006). In pursuit of these questions, the following section develops a number of hypotheses regarding the antecedents of psychic distance.

\section{ANTECEDENTS OF PSYCHIC DISTANCE}

\section{Formation of Psychic Distance Perceptions}

The shifting definition of psychic distance as employed in the IB literature reflects a parallel, but unstated, shift in the underlying assumptions regarding the formation of psychic distance perceptions - a subject on which the literature is surprisingly silent. In the Uppsala school's early conceptualization (Hörnell et al., 1973), psychic distance is primarily a cognitive category capturing the knowledge and amount of information individuals have (or believe they have) of other countries. Its primary determinants are therefore the cost or difficulty of obtaining relevant and accurate information regarding foreign business conditions and markets. According to this line of reasoning, psychic distance affects decisions regarding foreign activities by preventing managers from making fully informed, economically rational decisions. In the Uppsala School's early conceptualization, differences in culture are potentially problematic primarily because they are believed to increase information requirements and search costs.

The subsequent practice in the literature to treat cultural distance as synonymous with or as proxy for psychic distance deemphasizes the role of information access in favor of a focus on the (additional) costs that managers believe to be associated with operations in a culturally unfamiliar environment. According to Kogut and Singh (1988, p. 415), such "costs may be perceptual only or accurate appraisals of the increased 
difficulties of managing a foreign workforce in a culturally distant country." In contrast to the Uppsala school, this approach assumes that the costs and availability of relevant information about different countries differ only marginally and that the core challenges of doing business abroad are associated with absolute differences in country cultures. Moreover, since cultural differences between countries are symmetrical it is assumed that the difficulties of transferring and adapting business practices between any two countries are the same regardless of direction.

The hypotheses developed in the following section attempt to combine and reconcile the logics of the two approaches. We assume that psychic distance perceptions are formed on the basis of environmental stimuli, primarily the amount and type of information a person possesses about a foreign country. This, in turn, will be influenced by a range of factors, some of which are historically determined. Common language, for example - often a legacy of former colonial ties - is significant not only in facilitating communication and information exchange; it is often associated also with deeper cultural affinities affecting psychic distance perceptions.

The value and usefulness of information about a foreign country depend not only on its quantity and content, but also on the recipient's ability to correctly interpret it. This will tend to be the more difficult the more different the cultural and institutional contexts are to which the information refers. Cultural differences are important in that they affect individuals' abilities both to intellectually understand and to emotionally relate to conditions in foreign countries. The more familiar the impression of a foreign country is to the home country (or other countries with which the subject is familiar), the greater the psychic distance. Perceptions of psychic distance - like those of tourist destinations and goods of different national origin - are also affected by personal factors, such as individuals' values, motivation and prior experience, which may, in turn, be associated with various demographic characteristics (Balougu and McCleary, 1999). Such differences and their determinants are objects well worthy of further study. However, for the purposes of the present study, variations between individuals are assumed to be small and random, and tend to cancel one another out. 


\section{Hypotheses}

As discussed above, the prevailing view in the literature emphasizes cultural distance as a prime determinant of psychic distance (Boyacigiller, 1990; Evans et al., 2000; Johanson and Vahlne, 1977). Commonalities in religion, values and norms facilitate interaction and communication by providing shared, oftentimes tacit understandings of context and expectations of behavior. To the degree that cultures differ, the mutual understandings get blurred and communication becomes more difficult (Adler, 1986/1997). The greater the cultural distance between the home and the host country, the more difficult it will be both to obtain and to accurately interpret available information about a foreign market (Eriksson, Majkgard and Sharma, 2000; Sousa and Bradley, 2006). In consequence, cultural distance should have a direct bearing on psychic distance:

Hypothesis 1: The larger the cultural distance between two countries, the higher the perceived psychic distance between them.

Geographic proximity lowers transportation and communication costs and therefore facilitates personal interaction, information exchange and international trade (Johanson and Wiedersheim-Paul, 1975; Ghemawat, 2001). Of course, improvements in transportation and communication technologies have radically reduced the 'friction' of distance, in some instances - as in the case of Internet telephony reducing it to zero. This has clearly had - and will continue to have - a massive impact on the international flows of both physical goods and information. However, as Learner and Storper (2001) have argued, many transactions require trust and mutual understandings that can only be created in face-to-face interaction, where geographical distance continues to play a role. Moreover, as elsewhere in the social sciences, 'history matters'; for centuries, the pattern of international interaction was largely determined by absolute geographical distances. The path-dependent legacy of this fact is perhaps most clearly evident in the content of the history curricula of schools and universities the world over, where proximate countries are given more weight and attention than more distant ones. 
Hypothesis 2: The higher the geographic distance between two countries the higher the perceived psychic distance between them.

The perhaps most important legacy of history for psychic distance perceptions is the presence of a common language. The significance of this factor goes beyond the central fact that it increases access to information about a foreign country, allowing managers to use also information sources intended primarily for domestic use. It also goes beyond the advantages associated with being able to conduct business and manage employees in a familiar language. The presence of a common language is often associated with deeply rooted colonial or other historical ties, which, in turn, give rise to a range of circumstances that act to reduce psychic distance perceptions. These include a wide range of factors, from common nursery rhymes and culinary traditions over sports events and cultural exchanges to political alliances and everyday news coverage (Brewer, 2007).

Hypothesis 3: When countries have at least one language in common, this tends to reduce the perceived psychic distance between them.

Economic development is associated with a range of institutional, socio-economic and demographic factors affecting the structure and mores of society. We hypothesize that similarity in economic development and associated structural characteristics facilitate the flow of information and increase the probability that it be correctly interpreted (Hörnell et al., 1973; Johanson and Wiedersheim-Paul, 1975; Evans and Mavondo, 2002). As Dow and Karunaratna (2006:582) point out, “... the norms of business-to-business communication and interaction are... likely to be heavily influenced by the nature of the economy, and thus by the level of economic development. For example, the communication and business norms in a subsistence agrarian economy are likely to be dramatically different from those of a highly industrialized economy with a large service sector." Conversely, the greater the economic, institutional and structural differences between countries, the greater perceived psychic distances are likely to be:

Hypothesis 4: The larger the differences in economic development between two countries, the higher the perceived psychic distance between them. 
As pointed out already by Vahlne and Wiedersheim-Paul (1973), well developed economies have better developed infrastructures for the collection, analysis and dissemination of economic data and market information. For an observer from a foreign country, the level and quality of information available is likely to increase with the economic development of the target country and the strength of its institutional infrastructure (Ghemawat, 2001).

Hypotheses 5: The level of economic development in the target country negatively affects the perceived psychic distance to it.

Large and economically strong countries are able to exercise their influence on surrounding countries and on the rest of the world more pervasively than small countries can. Large economies act as suppliers and buyers of large shares of manufactured goods and are able to influence geo-policy through military strength and political clout. In consequence, larger countries receive more news coverage than smaller nations do. The most obvious instance of the size factor is the pervasive cultural influence of the U.S. through movies, television and the Internet on the rest of the world. In many parts of the world, managers have been exposed to American television series almost from birth and have been confronted with news from the U.S. since they started reading newspapers. Through this familiarity, they often - perhaps misleadingly (Ågren, 1990; O'Grady and Lane, 1996) - perceive the U.S. to be psychically close. ${ }^{4}$ Moreover, the influence of dominating countries on the perception of those dominated is evident also elsewhere. Austrian press coverage of Germany is significantly higher than German press coverage of its smaller neighbor, and Belgian newspapers are more likely to report on developments in France than the other way around. This, of course, is not surprising; developments in larger countries usually have more impact outside their borders that do events in smaller ones.

Hypothesis 6: The larger the economy of the target country, the lower is the perceived psychical distance to it. 


\section{METHOD}

\section{Sample}

Data collection on our dependent measure took place from fall 2003 till spring 2008. For the purpose of this study we selected the 25 largest countries, as measured by their absolute GDP in 2001: Argentina, Australia, Austria, Belgium, Brazil, Canada, China, Denmark, France, Germany, India, Italy, Japan, Mexico, Netherlands, Norway, Poland, Russia, South Korea, Spain, Sweden, Switzerland, Turkey, United Kingdom and USA. ${ }^{5}$ Collaborators were identified in all 25 countries to help with the collection of data in their respective home markets. Our objective was to target for the questionnaire academically trained managers mastering the English language and with four or more years of business experience, i.e. people with a background typical of managers involved in international business decisions. We therefore directed the questionnaire to executive MBA students and alumni of the partner universities.

All data were collected through an Internet-based survey instrument. Prospective respondents were invited to participate in the study via a customized email, containing a link to the survey. Secure server access as well as the collection of the respondents' IP addresses ensured that only invited participants could complete the survey and that responses were only collected once for each individual IP address. Our sampling efforts let to a total of 1608 usable responses. ${ }^{6}$ On average, respondents had 18 years of formal education (e.g. a first university degree in most countries) and 11 years of work experience. $72 \%$ of our respondents were male (Table 1). Cross-checking the demographics of our sample with relevant OECD data did not reveal any large discrepancies, suggesting that our sample is roughly in line with the target population of this study.

The questionnaire was designed to minimize the methodological hazards of administering an Englishlanguage questionnaire to non-native speakers from different cultural contexts (Singh, 1995). As Harzing et al. (2007) have shown, the ranking procedure employed helped alleviate not only the problems introduced by using a non-native language questionnaire (Harzing et al., 2005; Harzing, 2006; Ralston, Cunniff and Gustafson, 1995) but also those associated with differences in response styles in different cultures (Baumgartner and Steenkamp, 2001; Smith, 2004, Harzing, 2006). 
Insert Table 1 about here

\section{Dependent Variable}

The key objective of the study was to assess the psychic distances between the 25 countries. Respondents were asked to indicate to what extent they perceived foreign countries to be close or far away, in terms of psychic distance, from their home countries. In line with the definition adopted for the study "psychic distance' was defined in the questionnaire as the "sum of factors (cultural or language differences, geographical distance, etc.) that affect the flow and interpretation of information to and from a foreign country." Adapting a methodology first employed by Nordström (1990) and with slight variations also by Dow (2000) and Ellis (2007), we anchored a psychic distance scale from 0 to 100 by asking the respondents to set the distance to their home country to ' 0 ' and the distance to the country on the list that they perceived be the most distant to ' 100 '. Respondents were asked to assign index values for the remaining countries so that they reflected their relative perceived distance from both their home country and the one they considered to be most distant. For countries that were judged to be of equal distance, respondents were asked to assign the same score. On completion of the ranking, a sorted list was displayed listing the countries in ascending order, allowing respondents to make corrections where necessary. The dependent variable in this study is the average perceived psychic distance of the respondents from each country to the other 24 countries (Table 2).

Insert Table 2 about here

\section{Independent Variables}

Cultural distance. In the stream of general macroscopic research that attempts to frame and measure cultures along a few dimensions (including, e.g. House, et al. (2004), Kluckhohn and Strodtbeck (1961), Ronen and 
Shenkar (1985), Trompnaars (1993), and Schwartz (1992)), none has had the impact on IB literature as the seminal work of Hofstede $(1980,2001)$. A major reason for this was the inspired idea by Kogut and Singh (1988) to use Hofstede's dimensions and data to calculate an overall index for cultural distance.

In this paper, we follow this practice and measure cultural distance in terms of overall differences in cultural values according to the Kogut and Singh (1988) index, whereby the cultural distance ( $\left.\mathrm{CD}_{\mathrm{x} y}\right)$ between country $\mathrm{x}$ and $\mathrm{y}$ is calculated as the average of the differences of Hofstede's (1980) country scores adjusted by the variance $\left(\mathrm{v}_{\mathrm{i}}\right)$ of the corresponding dimension:

$$
\left.\mathrm{CD}_{\mathrm{xy}}=\Sigma\left\{\left(\mathrm{I}_{\mathrm{ix}}-\mathrm{I}_{\mathrm{iy}}\right)^{2} / \mathrm{V}_{\mathrm{i}}\right)\right\} / 4
$$

where $\mathrm{I}_{\mathrm{ix}}$ stands for the index for the ith cultural dimension and country $\mathrm{x}, \mathrm{V}_{\mathrm{i}}$ is the variance of the index of the ith dimension, the subscript y indicates country $y$.

Recently, several critical reviews have questioned the validity of the Kogut and Singh index (Brewer, 2007; Kirkman, et al., 2006; Harzing, 2004; Shenkar, 2001; Sousa and Bradley, 2004; Stöttinger and Schlegelmilch, 1998). Target for critique has been, among other things, the prevalent use of only Hofstede's four original dimensions of culture, disregarding the later added dimension 'long-term orientation', and the implicit assumption of equivalence, i.e. that differences along the various dimensions are equally problematic. Against this background, we subsequently explore the significance of cultural distance for psychic distance using the Kogut and Singh index both with four and with five dimensions (ITIM, 2007). As suggested by Shenkar (2001), we also explore the relative importance of differences along the individual cultural dimensions.

Geographical distance. Geographical distances were collected from the distance matrices available by the Paris based Centre d'études prospectives et d'informations internationales (CEPII). CEPII provides pair-wise country distance measures (in kilometers) both based on the distances between countries' major cities (in most cases the capitals) or as a weighted average between major population centers. The results reported below are based on the former. In the regression analyses, both gave near identical results. 
Common language. This dummy variable takes the value ' 1 ' when at least one of the official or de facto official languages of a country is the same as those of another; it is otherwise ' 0 ' (CIA 2005).

Differences in economic development. Differences in economic development were measured as the absolute difference in gross domestic product per capita (in USD) in 2004 (CIA 2005).

Economic development. The level of development of the target country was approximated by its gross domestic product per capita (in USD) in 2004 (CIA 2005).

\section{FINDINGS AND DISCUSSION}

\section{Descriptive Statistics}

The hypotheses were tested by means of OLS regressions. Preceding the statistical analysis, we tested the assumptions of linear regression: linearity, equality of variance and normality. Plotting standardized residuals against standardized predicted values showed no major violations of these assumptions. We examined the variance inflation factors (VIF) and all of the scores were below 2.3. A coefficient variance decomposition analysis with condition indices (cf. Hair, Anderson, Tatham and Black 1998) confirmed that multicolinearity was not a serious problem. Descriptive statistics and correlations are presented in Table 3.

Insert Table 3 about here

\section{Testing the Hypotheses}

As shown in Table 4, the analyses provide consistent support for Hypotheses 1, 2, 3 and 5. Both cultural distances (as operationalized by the Kogut and Singh index based on four Hofstede dimensions) and absolute geographical distances between countries strongly increase the perceived psychic distance between them; the presence of a common official language decreases distance perceptions. As expected, increasing GDP/capita 
in the target country - as indicator of its level of economic development - tends to decrease the perceived distance to it.

Insert Table 4 about here

According to Hypothesis 4, differences in per capita incomes were expected to positively affect psychic distance. Regression 4 confirms this assumption, but with the introduction of measurements for per capita income in the target country in Regressions 6 and 7, the significance of this variable declines sharply.

The analysis gives no support for Hypothesis 6 - that larger and more dominant countries are perceived as being closer than smaller ones. The coefficient for absolute level of GDP of the target country takes the expected negative sign but is not significant. The size of the target economy does not therefore seem to affect the perceived distance to it. The result is somewhat puzzling in view of the observed asymmetries in the distance perceptions between many pairs of countries, perhaps suggesting that more sophisticated measures may be needed to capture the assumed 'dominance effect'.

\section{Cultural Distance vs. Psychic Distance}

The regression results confirm the statistically significant influence of cultural distance, as conventionally operationalized by the four-dimension version of the Kogut and Singh index. However, its weak overall correlation with perceived psychic distance is surprising, given the measure's dominance in the literature and the tendency to employ it as an overall proxy also for psychic distance. In view of the critique of the measure already referred to and in the absence of any clear theoretical reasons to prefer one operationalization over the other, regressions 7-10 explored four different approaches to measure cultural distance with the help of Hofstede's dimensions and measurements (ITIM, 2007). The results are reported in Table 5 . 
Insert Table 5 about here

The results fail to validate Kogut and Singh's (1988) claim that cultural distance is essentially similar to psychic distance and the subsequent tendency in much of the literature to treat the one as an interchangeable substitute for the other. 'Cultural distance' may well contribute to perceptions of 'psychic distance', but the two constructs clearly measure different things (Dow, 2000; Ellis, 2007; Nordström \& Vahlne, 1994). This is especially true for the most commonly employed measure, the Kogut and Singh index calculated on the basis of Hofstede's original four dimensions. As Regression 1 shows, the adjusted R ${ }^{2}$ with 'Kogut Singh (4)' as the sole independent variable amounts to a mere .062, corresponding to a simple correlation of not more than .25. Interestingly, including differences also in 'long term orientation' in the computation of the Kogut and Singh index (Regression 8) increases its explanatory power dramatically. ${ }^{7}$ The same is true when differences in the individual culture dimensions are included separately (Regressions 7 and 9). It appears that differences in 'individualism' and 'long term orientation' are much more significant than those regarding 'masculinity' and 'uncertainty avoidance' as antecedents to psychic distance perceptions.

The results throws into doubt the practice of using cultural distance as measured by the Kogut and Singh index as a direct proxy for psychic distance. As pointed out in several critical reviews (Brewer, 2007; Kirkman, et al., 2006; Harzing, 2004; Shenkar, 2001; Sousa and Bradley, 2004; Stöttinger and Schlegelmilch, 1998) and, indeed, by the inventors of the index themselves, its primary attraction is the ease with which it can be computed rather than its validity or reliability - both of which appear to be rather dubious: 
The indices of Hofstede can be criticized for a number of reasons, especially regarding the internal validity of the dimensions and the method of constructing the scales. Whereas the criticism has a sound basis, Hofstede's study has some appealing attributes, namely, the size of the sample, the codification of cultural traits along a numerical index, and its emphasis on attitudes in the workplace. (Kogut and Singh, 1988: 422, italics added).

Among the disadvantages of Hofstede's dimensions for the purpose of estimating perceptions of psychic distance is their disregard for overt and easily recognized cultural expressions such as those associated, for example, with religion, architecture, and art. Moreover, the correlation of cultural distance, as measured by the Kogut and Singh index, with perceived psychic distance appears itself to be culturally dependent (Figure 1). As Hofstede (2001) himself was acutely aware and repeatedly pointed out, his identification of cultural dimensions is itself culturally contingent, i.e. reflects his own cultural perspective. In apparent confirmation of this, the correlations between the perceptions of psychic distances and the Kogut and Singh index are relatively high for the Netherlands and countries culturally proximate to it. For culturally more distant countries, no correlation can be detected. Here, it appears, Hofstede's cultural dimensions are irrelevant for people's perceptions. Since most IB research has focused on firms from countries belonging to the cluster of countries in the upper left hand corner of Figure 1 and has been undertaken by researchers from these same countries, this finding may help to explain why - in spite of its apparent shortcomings - the Kogut and Singh index has obtained its dominance in the IB literature.

Insert Figure 1 about here 


\section{CONCLUSION}

\section{Implications}

Our study has a number of important implications. Above all, our results demonstrate that perceived psychic distance is influenced by a complex array of factors and cannot reliably be approximated by cultural distance only. Geographical proximity and economic factors are also powerful antecedents of perceived psychic distances between countries. Indeed, simple geographical distance turns out to be more than three times as important as cultural distance as measured by the Kogut and Singh index (in both its four and its five dimensional forms). This suggests that, in most countries, cultural distance alone is a weak predictor of perceived psychic distance, especially in the prevalent form of using only the original four dimensions. Scholars empirically investigating international business decisions for which psychic distance perceptions may be important should strive for more robust measures. Although their validity for such purposes remains to be empirically verified, direct measures such as those developed for this paper (presented in detail in Table 2) would seem on a priori grounds to offer an attractive option. Of course, obtaining such data for countries other than the 25 large economies surveyed here may not always be feasible. In such instances, the methodological implications of our results are (1) that the five-dimension version of the Kogut and Singh index is preferable to its four-dimension counterpart, and (2) that absolute geographical distance - another easily obtainable measure - should be included as a correlate.

The results also have implications for the operational construction of formative psychic distance constructs (Brewer, 2007; Vahlne \& Wiedersheim-Paul, 1977), as our results suggest that economic, geographic and cultural distance should not be equally weighted. Studies that attempt to capture perceptional distances by means of a simple cultural distance index run the risk of making attribution errors (Shenkar, 2001). The failure to include other distance-related variables may lead to erroneous conclusions as to the influence of cultural distance on decisions regarding market selection, entry modes or foreign subsidiary performance. 


\section{Avenues for Further Research}

The argument outlined in this paper is based on a distinction between 'objective' and 'perceived' psychic distance - an idea that has rarely been explicitly discussed, but that we believe to be consistent with the implicit assumptions of most of the literature. It has long been assumed, for example, that the significance of absolute and cultural distance tends to diminish with experience (Hörnell et al., 1973; Benito and Gripsrud, 1992). Since experience is idiosyncratic to the individual, its effect will tend over time and through unique personal experience to vary in ways that are difficult to predict. In the above analysis, we assumed supported by statistical analysis - that the effects of idiosyncratic individual experience can be included in the error term, i.e. they are generally small, normally distributed and have an expected value of zero. On the basis of this assumption, predictions of average firm behavior can be based on measures of average psychic distance. However, whether or not this assumption can be upheld is an issue in need of empirical investigation. The 'born global' phenomenon of firms rapidly entering very distant markets suggests, for example, that the variance in the psychic distance perceptions of individual managers has increased, perhaps dramatically, over time.

One criticism of previous studies has been the - usually implicit - treatment of cultural and psychic distances as symmetric (Shenkar, 2001), i.e. assuming that such distances (like geographic ones) are the same regardless of direction. While our data descriptively confirms the existence of considerable asymmetry, our statistical analysis did not well reveal the sources of this. While the level of development of the target country did appear to significantly affect perceptions, the size of its economy had no such effect. Exploring both alternative operationalizations of 'dominance' and the possible influence of other variables, also ones pertaining to the country of origin, offers a potentially fruitful area for future research.

The issue is part of the underresearched problem of how psychic distance perceptions are formed at the individual level. To address this, results from tourism research on the formation of destination images may by analogy provide important hints. The process of whereby psychic distance perceptions are formed that affect business decisions - such as the choice of export markets or modes of entry into foreign markets - has 
clear parallels to how destination images affecting tourists choice of holiday locations are formed. Studies of the formation of destination images suggest that psychic distance perceptions contain both cognitive and affective elements and are influenced by both personal factors and environmental stimuli (Balougu and McCleary, 1999; Hosany, Ekinci and Uysal, 2006; Ryan, 2005). There is at present little knowledge available as to how affective/attitudinal factors may also influence perceptions of psychic distance and the other way around. Similarly, the influence of personal factors, such as values, motivations and previous experience, has been given little attention in the literature (for an exception see Sousa and Bradley, 2006). Both are promising areas for future research.

Of course, measures of 'psychic distance' - as here defined - are relevant primarily to decisions and behavior influenced by managerial perceptions. They do not necessarily throw much light on questions regarding, for example, the performance of foreign subsidiaries, which can be expected to depend on 'objective' differences - such as 'cultural distance' - between home and target countries. As suggested by O'Grady and Lane (1996), the relationship between perceived and real distances is a further area worthy of research. The fact that such perceptions are not symmetrical suggests that the 'psychic overconfidence' may be a more important issue for firms from some countries than from others (Evans \& Mavondo, 2002; Fenwick, Edwards \& Buckley, 2003; Pedersen and Petersen, 2004).

\section{NOTES}

${ }^{1}$ The issue is an important one for IB research. In a survey of the literature, we identified 148 empirical studies employing the Kogut/Singh index. In 60 (40\%) of these, the index was used as a proxy for ex ante managerial perceptions of psychic distance to foreign countries, influencing choice of foreign market selection and entry modes. In the remainder, the index was used as an indication of the ex post ease/difficulty of doing business in foreign markets, influencing various aspects of the performance of international joint ventures and foreign subsidiaries (38\%), human resource practices (11\%) and other IB phenomena (11\%)

${ }^{2}$ The term seems to have been chosen in order to emphasize that it refers to perceived rather than absolute distances. Other than this, it has no 'psychological' or, indeed, 'psychic' connotations. 
${ }^{3}$ Over time, the origins of the idea have tended to be forgotten. Stöttinger and Schlegelmilch $(1998,2000)$, for example, suggest that psychic distance is a concept "beyond its due date" on the ground that export sales to psychically more distant countries are sometimes higher than to psychically proximate ones, as in the case of U.S. American exports to Mexico and Germany, respectively.

${ }^{4}$ As table 2 indicates (see below), the converse is also true. Only three countries perceive the distance to the US to be higher than 50 (Russia, Turkey and Japan). U.S. Americans in turn perceive only three countries as being below 40 (Mexico, Canada and the UK).

${ }^{5}$ Saudi Arabia (rank 23) was substituted by Turkey (rank 27) since one of the objectives of our study was to compare our data on perceived psychic distance index with Hofstede's (1980) cultural dimensions, for which we could not find estimates for Saudi Arabia.

${ }^{6}$ We decided to delete all observations where the nationality and mother tongue of the respondent did not match the country in which the survey was conducted (e.g. Turkish respondents living in Austria, or Chinese citizens in Australia). In Switzerland, Belgium and Canada, only respondents were included who had indicated as mother tongue respectively German, Flemish or English. The measurements pertaining to these countries reported in Table 2 are therefore not necessarily representative of nationals from these countries with other linguistic backgrounds.

${ }^{7}$ Replacing the four-dimension Kogut and Singh index in Regression 6 (Table 4) by its five-dimension equivalent significantly increases the adjusted R2 value from .723 to .769 with only marginal changes to other regression estimates. 


\section{REFERENCES}

Adler, N. J. (1986/1997) 'International Dimensions of Organizational Behavior', $3^{\text {rd }}$ ed, South-Western College Publishing: Cincinnati, Ohio.

Aharoni, Y. (1966) The Foreign Investment Decision Process: Boston, MA.

Baloglu, S. and McCleary (1999) 'A Model of Destination Image Formation', Annals of Tourism Research 26(4): 868-897.

Baumgartner, H. and Steenkamp, J.-B. E.M. (2001) 'Response Styles in Marketing Research: A CrossNational Investigation', Journal of Marketing Research 38 (May): 143-156.

Beckerman, W. (1956) 'Distance and the Pattern of Intra-European Trade', The Review of Economics and Statistics 38(1): 31-40.

Benito, G. and Gripsrud, G. (1992) 'The Expansion of Foreign Direct Investments: Discrete Rational Location Choices or a Cultural Learning Process?', Journal of International Business Studies 23(3): 461-476.

Björkman, I. and Furu, P. (2000) ‘Determinants of Variable Pay for Top Managers of Foreign Subsidiaries in Finland', International Journal of Human Resource Management 11(4): 698713.

Brewer, P.A. (2007) 'Operationalizing Psychic Distance: A Revised Approach', Journal of International Marketing 15(1): 44-66.

Brock, D.M., Shenkar, O., Shoham, A. and Siscovick, I.C. (2008) 'National Culture and Expatriate Deployment.' Journal of International Business Studies 39: 1-17.

Burenstam Linder, S. (1961) An Essay on Trade and Transformation. Almqvist \& Wiksell: Uppsala.

CEPII (2007) Centre d'études prospectives et d'informations internationals, http://www.cepii.fr/anglaisgraph/bdd/distances.htm, accessed on June 23, 2007.

CIA (2005) TheWorld Factbook 2005. http://www.umsl.edu/services/govdocs/wofact2005/index.html, accessed on June 11, 2007.

Cyert, R.M. and March, J.G. (1963) A Behavioral Theory of the Firm, Englewood Cliffs, NJ. 
Dow, D. (2000) 'A Note on Psychological Distance and Export Market Selection', Journal of International Marketing 8(1): 51-64.

Dow, D. and Karunaratna, A. (2006) 'Developing a multidimensional instrument to measure psychic distance stimuli', Journal of International Business Studies 37: 578-602.

Ellis, P.D. (2007) 'Paths to Foreign Markets: Does Distance to Market Affect Firm Internationalisation?', International Business Review 16: 573-593.

Ellis, P.D. (2008) ‘Does Psychic Distance Moderate the Market Size-Entry Sequence Relationship?’, Journal of International Business Studies 39: 351-369.

Eriksson, K., Majkgard, A. \& Deo Sharma, D. (2000) 'Path Dependence and Knowledge in the Internationalization Process', Management International Review, 40: 307-328.

Evans, J. A. and Mavondo, F. (2002) 'Psychic Distance and Organizational Performance: An Empirical Examination of International Retailing Operations', Journal of International Business Studies 33(3): $515-532$.

Evans, J., A. Treadgold and Mavondo, F. (2000a) 'Explaining Export Development through Psychic Distance', International Marketing Review 17(2): 164-168.

Evans, J., Treadgold, A. and Mavondo, F. (2000b) 'Psychic Distance and the Performance of International Retailers. A Suggested Theoretical Framework', International Marketing Review, 17(4/5): 373-391. Fenwick, M., Edwards, R., and Buckley, P.J. (2003) 'Is Cultural Similarity Misleading? The Experience of Australian Manufacturers in Britain', International Business Review 12: 297-309.

Ghemawat, P. (2001) 'Distance Still Matters: The Hard Reality of Global Expansion', Harvard Business Review, 79(September): 137-147.

Ghemawat, P. (2003) 'The Forgotten Strategy', Harvard Business Review 81(11): 76.

Griffith, D. A. and Harvey, M.G. (2001) ‘A Resource Perspective of Global Dynamic Capabilities’, Journal of International Business Studies 32(3): 597 - 606.

Hair, J.F. Anderson, R.E. Tatham, R. L. and Black, W.C. (1998) Multivariate Data Analysis. Prentice-Hall: Upper Saddle River, NJ. 
Harzing, A.-W. (2004) ‘The Role of Culture in Entry-Mode Studies: From Neglect to Myopia?', Advances in International Management 15: 75-127.

Harzing, A.-W. (2006) 'Response Styles in Cross-National Survey Research: A 26-Country Study', International Journal of Cross Cultural Management 6(2): 243-266.

Harzing, A.-W. \& 32 country collaborators (2005) 'The Use of English Questionnaires in Cross-National Research: Does Cultural Accommodation Obscure National Differences?' International Journal of Cross Cultural Management 5(2): 213-224.

Harzing, A.-W. \& 22 country collaborators (2007) 'Ranking and Rating in Native-Language versus EnglishLanguage Questionnaires: A Methodological Comparison. Paper presented at the $33^{\text {rd }}$ EIBA Conference in Catania, December 13-15, 2007.

Hofstede, G. (1980) Culture’s Consequences: International Differences in Work-related Values. Sage: Beverly Hills, CA.

Hofstede, G. (2001). Culture's Consequences: Comparing Values, Behaviors, Institutions and Organizations across Nations. Sage: Beverly Hills, CA.

Hosany, S., Ekinci, Y. and Uysal, M. (2006) 'Destination Image and Destination Personality: An Application of Branding Theories to Tourism Places', Journal of Business Research 59: 638642

Hörnell, E., Vahlne,J.-E., and Wiedersheim-Paul, F. (1973) Export och utlandsetableringar, Almqvist \& Wiksell: Stockholm.

House, R.J., Hanges, P.J., Javidan, M., Dorfman, P.W. and Gupta, V. (2004) Culture, Leadership and Organizations: The GLOBE Study of 62 Societies. Sage: London.

IMF (2005) Direction of Trade Statistics 2005. International Monetary Fund: Washington.

ITIM (2007) http://www.geert-hofstede.com/hofstede dimensions.php, accessed on June 11, 2007.

Johanson, J. and Vahlne, J.-E. (1977) 'The Internationalization Process of the Firm -A Model of Knowledge Development and Increasing Foreign Market Commitments', Journal of International Business Studies 8(1): 25-34. 
Johanson, J. and Wiedersheim-Paul, F. (1975) ‘The Internationalization of the Firm: Four Swedish Cases'. Journal of Management Studies 12(3): 305-322.

Kirkman, B.L., Lowe, K.B. \& Gibson, C.B. (2006) ‘A quarter century of Culture’s Consequences: a review of empirical research incorporating Hofstede's cultural values framework'. Journal of International Business Studies, 37, 285-320.

Kluckhohn, F.R. \& Strodtbeck, F.L. (1961) Variations in Value Orientations. Peterson: Evanston, IL. Kogut, B. and Singh,H. (1988) 'The Effect of National Culture on the Choice of Entry Mode', Journal of International Business Studies 19(3): 411-432.

Lu, L.-T. (2006) 'The Relationship between Cultural Distance and Performance in International Joint Ventures: A Critique and Ideas for Further Research'. International Journal of Management 23(3): 436-445.

March, J.G. and Simon, H.A. (1958/1993) Organizations. (2 ${ }^{\text {nd }}$ ed.) Blackwell: Cambridge.

McSweeney, B. (2002) ‘Hofstede’s Model of National Cultural Differences and Their Consequences: A Triumph of Faith - a Failure of Analysis', Human Relations 55(1): 89-118.

Minbaeva, D., Pedersen, T., Björkman, I., Fey, C.F. and Park, H.J. (2003) MNC Knowledge Transfer, Subsidiary Absorptive Capacity, and HRM', Journal of International Business Studies 34(6): 586-599 Muralidharan, R. and Phatak, A. (1999) 'International R\&D Activity of US MNCS: An Empirical Study with Implications for Host Government Policy', Multinational Business Review 7(2): 97-105.

Nordström, K.A. (1990) The Internationalization Process of the Firm: Searching for New Patterns and Explanations. Ph.D. dissertation, Stockholm: Institute of International Business, Stockholm School of Economics.

Nordström, K.A. and Vahlne, J.E. (1994) 'Is the Globe Shrinking? Psychic Distance and the Establishment of Swedish Sales Subsidiaries during the Last 100 Years', In: M. Landeck (Ed.), International Trade: Regional and Global Issues. St Martin's Press.

O'Grady, S. and Lane, H.W. (1996) 'The Psychic Distance Paradox', Journal of International Business Studies 27(2): 309-333. 
Pedersen, T., and Petersen, B. (2004) 'Learning about Foreign Markets: Are Entrant firms Exposed to a “Shock Effect”?' Journal of International Marketing 42(2): 7-29.

Ralston, D.A., Cunniff, M.K. \& Gustafson, D.J. (1995) 'Cultural Accommodation: The Effect of Language on the Response of Bilingual Hong Kong Chinese Managers', Journal of Cross-Cultural Psychology, 26 (6): 714-727.

Rao, A. and Schmidt, S.M. (1998) ‘A Behavioral Perspective on Negotiating International Alliances', Journal of International Business Studies 29(4): 665 - 694.

Ronen, S. and Shenkar, O. (1985) 'Clustering Countries on Attitudinal Dimensions: A Review and Synthesis', Academy of Management Review 10(3): 435-454.

Rosenzweig, P. M. and Nohira, N. (1994) 'Influences on Human Resource Management Practices in Multinational Corporations'. Journal of International Business Studies 25(3): 229-251.

Ryan, C. (2005) 'Structuring Destination Image: A Qualitative Approach', Journal of Travel Research 44: 143-150.

Schwartz, S.H. (1992) 'Universals in the Content and Structure of Values: Theoretical Advances and Empirical Tests in 20 Cultures', In: M.P. Zanna (Ed.). Advances in Experimental Social Psychology 25: 1-65. San Diego: Academic Press.

Shenkar, O. (2001) 'Cultural Distance Revisited: Towards a More Rigorous Conceptualization and Measurement of Cultural Differences', Journal of International Business Studies 32(3): 519-535.

Simon, H.A. (1947/1997) Administrative Behavior: A Study of Decision-making Processes in Administrative Organizations. $\left(4^{\text {th }}\right.$ ed.) The Free Press: New York.

Simonin, B. L. (1999) 'Transfer of Marketing Know-How in International Strategic Alliances: An Empirical Investigation of the Role and Antecedents of Knowledge Ambiguity', Journal of International Business Studies 30(3): 463-490.

Singh, J. (1995) 'Measurement Issues in Cross-national Research', Journal of International Business Studies, 26: $597-620$.

Smith, P.B. (2004) 'Acquiescent Response Bias as an Aspect of Cultural Communication Style', Journal of Cross-Cultural Psychology 35(1): 50-61. 
Sousa, C.M.P. and Bradley, F. (2005) ‘Global Markets: Does Psychic Distance Matter?’, Journal of Strategic Marketing 13: 43-59.

Sousa, C. M. P. and Bradley F. (2006) 'Cultural Distance and Psychic Distance: Two Peas in a Pod?' Journal of International Marketing 14(1): 49-70.

Stöttinger, B. and Schlegelmilch, B.B. (1998) 'Explaining Export Development through Psychic Distance: Enlightening or Elusive?’ International Marketing Review 15(5): 357-372.

Stöttinger, B. and Schlegelmilch, B.B. (2000) 'Psychic Distance: A Concept Past Its Due Date?' International Marketing Review 17(2): 169-173.

Tihanyi, L., Griffith, D.A. and Russell, C.J. (2005) The Effect of Cultural Distance on Entry Mode Choice, International Diversification, and MNE Performance: A Meta-analysis', Journal of International Business Studies 36(3): 270-283.

Trompenaars, F. (1993) Riding the Waves of Culture: Understanding Cultural Diversity in Business. London: Nicholas Brealy.

Vahlne, J.E. and Wiedersheim-Paul, F. (1973) Economic Distance: Model and Empirical Investigation, In: E. Hornell, Vahlne, J.E and Wiedersheim-Paul, F. (Eds.), Export and Foreign Establishments. Uppsala: University of Uppsala

Vernon, R. (1966) 'International Investment and International Trade in the Product Cycle', Quarterly Journal of Economics 80: 190-207.

Wilkingson, T.J., Peng, G.Z., Brouthers, L.E. and Beamish, P.W. (2008) 'The diminishing effect of cultural distance on subsidiary control', Journal of International Management 14: 93-107.

Zhao, H., Luo, Y. and Suh, T. (2004) 'Transaction Cost Determinants and Ownership-based Entry Mode Choice: A Meta-analytical Review. Journal of International Business Studies 35(6): 524-544. 
Table 1: Sample Characteristics across all 25 Countries

\begin{tabular}{|c|c|c|c|c|c|c|}
\hline Country & $\mathrm{N}$ & Age & $\begin{array}{l}\text { Male } \\
\text { share }\end{array}$ & $\begin{array}{l}\text { Business } \\
\text { experience } \\
\text { (years) }\end{array}$ & $\begin{array}{l}\text { Time aboard } \\
\text { (years) }\end{array}$ & $\begin{array}{c}\text { Education } \\
\text { (years) }\end{array}$ \\
\hline Argentina & 79 & 36 & $83 \%$ & 10.0 & 1.6 & 19.7 \\
\hline Australia & 48 & 40 & $77 \%$ & 13.9 & 3.7 & 18.2 \\
\hline Austria & 68 & 35 & $68 \%$ & 9.4 & 3.0 & 17.7 \\
\hline Belgium & 34 & 38 & $85 \%$ & 13.2 & 1.4 & 17.9 \\
\hline Brazil & 40 & 39 & $67 \%$ & 13.2 & 0.7 & 20.7 \\
\hline Canada & 29 & 35 & $59 \%$ & 8.3 & 4.2 & 18.7 \\
\hline China & 35 & 35 & $49 \%$ & 9.0 & 3.9 & 16.8 \\
\hline Denmark & 64 & 39 & $73 \%$ & 11.3 & 2.9 & 17.2 \\
\hline France & 98 & 34 & $68 \%$ & 11.0 & 4.0 & 18.1 \\
\hline Germany & 72 & 34 & $68 \%$ & 6.3 & 2.8 & 19.3 \\
\hline India & 47 & 30 & $98 \%$ & 4.3 & 2.0 & 19.0 \\
\hline Italy & 57 & 34 & $63 \%$ & 8.9 & 1.8 & 18.4 \\
\hline Japan & 34 & 37 & $78 \%$ & 12.7 & 1.9 & 15.7 \\
\hline Mexico & 103 & 37 & $58 \%$ & 11.3 & 2.2 & 19.4 \\
\hline Netherlands & 46 & 35 & $87 \%$ & 10.4 & 4.0 & 19.3 \\
\hline Norway & 43 & 39 & $72 \%$ & 12.6 & 3.6 & 17.3 \\
\hline Poland & 129 & 37 & $70 \%$ & 12.5 & 1.6 & 18.6 \\
\hline Russia & 57 & 37 & $53 \%$ & 10.7 & 1.9 & 17.5 \\
\hline South Korea & 35 & 38 & $85 \%$ & 8.7 & 3.4 & 17.1 \\
\hline Spain & 35 & 34 & $71 \%$ & 8.1 & 2.9 & 19.7 \\
\hline Sweden & 69 & 41 & $74 \%$ & 13.3 & 3.2 & 17.4 \\
\hline Switzerland & 48 & 42 & $94 \%$ & 14.9 & 1.7 & 18.7 \\
\hline Turkey & 45 & 38 & $80 \%$ & 10.8 & 2.0 & 17.8 \\
\hline UK & 64 & 40 & $78 \%$ & 13.5 & 2.2 & 18.4 \\
\hline USA & 35 & 40 & $57 \%$ & 11.6 & 0.7 & 17.7 \\
\hline
\end{tabular}


Table 2: Psychic Distance between the 25 Countries

\begin{tabular}{|c|c|c|c|c|c|c|c|c|c|c|c|c|c|c|c|c|c|c|c|c|c|c|c|c|c|}
\hline \multirow{2}{*}{$\begin{array}{l}\text { Distance } \\
\text { to }\end{array}$} & \multicolumn{25}{|c|}{ Distance From } \\
\hline & ARG & AUS & AUT & BEL & BRA & CAN & CHE & CHN & DEU & DNK & ESP & FRA & GBR & IND & ITA & JPN & KOR & MEX & NLD & NOR & POL & RUS & SWE & TUR & S \\
\hline ARG & 0 & 69 & 67 & 76 & 12 & 59 & 68 & 87 & 58 & 72 & 30 & 50 & 66 & 69 & 47 & 78 & 77 & 23 & 62 & 66 & 65 & 81 & 71 & 77 & 57 \\
\hline AUS & 60 & 0 & 55 & 67 & 59 & 47 & 56 & 46 & 42 & 39 & 62 & 47 & 40 & 43 & 65 & 34 & 41 & 59 & 48 & 43 & 52 & 81 & 46 & 80 & 53 \\
\hline AUT & 60 & 58 & 0 & 19 & 58 & 44 & 10 & 63 & 9 & 25 & 35 & 26 & 28 & 65 & 23 & 59 & 63 & 52 & 25 & 29 & 27 & 39 & 28 & 44 & 51 \\
\hline BEL & 58 & 59 & 24 & 0 & 54 & 42 & 24 & 63 & 15 & 24 & 31 & 9 & 24 & 59 & 23 & 58 & 66 & 49 & 8 & 29 & 28 & 40 & 26 & 43 & 50 \\
\hline BRA & 12 & 69 & 69 & 73 & 0 & 57 & 71 & 72 & 60 & 75 & 46 & 54 & 67 & 58 & 56 & 61 & 72 & 25 & 65 & 67 & 66 & 77 & 65 & 74 & 50 \\
\hline CAN & 44 & 30 & 44 & 47 & 39 & 0 & 39 & 48 & 32 & 36 & 51 & 30 & 29 & 48 & 51 & 41 & 35 & 23 & 36 & 32 & 44 & 58 & 34 & 63 & 10 \\
\hline CHE & 60 & 57 & 11 & 19 & 58 & 39 & 0 & 65 & 12 & 25 & 33 & 18 & 28 & 55 & 20 & 57 & 56 & 53 & 21 & 26 & 34 & 43 & 26 & 47 & 50 \\
\hline CHN & 92 & 59 & 90 & 81 & 79 & 77 & 93 & 0 & 91 & 87 & 85 & 90 & 87 & 43 & 88 & 33 & 21 & 68 & 90 & 88 & 91 & 56 & 85 & 78 & 79 \\
\hline DEU & 54 & 50 & 8 & 9 & 50 & 41 & 9 & 52 & 0 & 17 & 31 & 20 & 24 & 53 & 24 & 39 & 47 & 45 & 12 & 23 & 22 & 30 & 22 & 31 & 42 \\
\hline DNK & 63 & 57 & 23 & 24 & 62 & 41 & 25 & 60 & 16 & 0 & 40 & 28 & 25 & 60 & 34 & 59 & 61 & 55 & 17 & 9 & 29 & 42 & 13 & 53 & 56 \\
\hline ESP & 27 & 60 & 28 & 19 & 30 & 48 & 29 & 62 & 25 & 34 & 0 & 16 & 27 & 52 & 12 & 51 & 59 & 24 & 29 & 33 & 27 & 39 & 34 & 35 & 47 \\
\hline FRA & 48 & 49 & 24 & 8 & 41 & 37 & 16 & 48 & 22 & 31 & 20 & 0 & 22 & 52 & 14 & 42 & 45 & 38 & 21 & 32 & 28 & 34 & 32 & 38 & 48 \\
\hline GBR & 48 & 30 & 27 & 18 & 45 & 22 & 23 & 48 & 19 & 18 & 27 & 23 & 0 & 33 & 29 & 38 & 40 & 39 & 16 & 20 & 27 & 34 & 20 & 42 & 28 \\
\hline IND & 86 & 59 & 80 & 71 & 74 & 77 & 79 & 48 & 79 & 82 & 81 & 77 & 57 & 0 & 74 & 47 & 50 & 67 & 78 & 81 & 82 & 66 & 74 & 77 & 77 \\
\hline ITA & 36 & 48 & 17 & 22 & 35 & 47 & 19 & 56 & 25 & 36 & 16 & 16 & 29 & 47 & 0 & 42 & 5 & 36 & 28 & 37 & 25 & 34 & 34 & 28 & 46 \\
\hline JPN & 84 & 49 & 81 & 80 & 76 & 71 & 75 & 29 & 78 & 76 & 89 & 79 & 72 & 55 & 82 & 0 & 22 & 65 & 83 & 83 & 84 & 72 & 74 & 69 & 55 \\
\hline KOR & 89 & 63 & 86 & 88 & 82 & 81 & 87 & 25 & 86 & 86 & 88 & 87 & 83 & 57 & 86 & 29 & 0 & 73 & 85 & 86 & 89 & 72 & 81 & 75 & 68 \\
\hline MEX & 23 & 70 & 67 & 64 & 24 & 40 & 66 & 77 & 58 & 70 & 33 & 54 & 63 & 62 & 53 & 57 & 67 & 0 & 63 & 66 & 64 & 74 & 63 & 74 & 18 \\
\hline NLD & 58 & 57 & 20 & 7 & 60 & 41 & 19 & 62 & 13 & 16 & 35 & 25 & 19 & 59 & 30 & 58 & 51 & 54 & 0 & 19 & 28 & 40 & 20 & 44 & 56 \\
\hline NOR & 67 & 61 & 25 & 29 & 68 & 42 & 28 & 61 & 22 & 9 & 46 & 32 & 28 & 68 & 36 & 61 & 67 & 60 & 23 & 0 & 31 & 41 & 9 & 56 & 58 \\
\hline POL & 67 & 75 & 35 & 36 & 73 & 60 & 50 & 65 & 37 & 45 & 50 & 42 & 45 & 69 & 35 & 74 & 71 & 60 & 43 & 41 & 0 & 20 & 36 & 48 & 69 \\
\hline RUS & 77 & 81 & 60 & 59 & 80 & 70 & 67 & 41 & 57 & 65 & 64 & 60 & 59 & 52 & 54 & 63 & 56 & 67 & 64 & 63 & 30 & 0 & 56 & 41 & 70 \\
\hline SWE & 64 & 60 & 22 & 26 & 63 & 40 & 25 & 64 & 20 & 9 & 42 & 30 & 27 & 61 & 35 & 59 & 60 & 57 & 20 & 8 & 29 & 40 & 0 & 56 & 53 \\
\hline TUR & 78 & 78 & 53 & 43 & 76 & 74 & 57 & 78 & 54 & 61 & 65 & 62 & 52 & 60 & 49 & 63 & 48 & 67 & 50 & 63 & 59 & 36 & 58 & 0 & 80 \\
\hline USA & 36 & 29 & 47 & 43 & 29 & 6 & 37 & 44 & 30 & 30 & 42 & 37 & 28 & 44 & 49 & 24 & 22 & 15 & 33 & 31 & 40 & 54 & 31 & 50 & 0 \\
\hline
\end{tabular}


Table 3. Descriptive statistics

\begin{tabular}{llrr}
\hline Variable name & Mean & Standard deviation \\
\hline 1 & Mean Psychic Distance & 48.5 & 21.2 \\
2 & Kogut/Singh (4) & 2.08 & 1.4 \\
3 & Kogut/Singh (5) & 2.00 & 1.5 \\
4 & PDI difference & 23.7 & 16.5 \\
5 & IDV difference & 24.7 & 17.6 \\
6 & MAS difference & 24.6 & 19.2 \\
7 & UAI difference & 25.3 & 17.8 \\
8 & LTO difference & 25.5 & 23.0 \\
9 & Geographic distance (log) & 3.62 & .48 \\
10 & Common official language (dummy) & .08 & .27 \\
11 & GDP/Capita difference & 12,640 & 9,711 \\
12 & GDP/Capita destination & 23,308 & 11,050 \\
13 & GDP destination & $1,773,700$ & $2,541,590$ \\
\hline
\end{tabular}

Correlation matrix $(\mathrm{n}=600)$

\begin{tabular}{|c|c|c|c|c|c|c|c|c|c|c|c|c|c|}
\hline & 1 & 2 & $3^{1)}$ & 4 & 5 & 6 & 7 & $8^{1)}$ & 9 & 10 & 11 & 12 & 13 \\
\hline 1 & -- & & & & & & & & & & & & \\
\hline 2 &, $252^{*}$ & -- & & & & & & & & & & & \\
\hline $3^{1)}$ &, $478^{*}$ & $891^{*}$ & -- & & & & & & & & & & \\
\hline 4 &, $206^{*}$ &, $663^{*}$ &, $593^{*}$ & -- & & & & & & & & & \\
\hline 5 &, $413^{*}$ &, $475^{*}$ &, $673^{*}$ &, $264^{*}$ & -- & & & & & & & & \\
\hline 6 & -,045 &, $501^{*}$ &, $269^{*}$ & ,088* &,$- 132^{*}$ & -- & & & & & & & \\
\hline 7 & ,066 & ,611 &, $368^{*}$ &, $295^{*}$ & ,132 & $184^{*}$ & -- & & & & & & \\
\hline $8^{1)}$ &, $557^{*}$ &, $515^{*}$ &, $794^{*}$ &, $364^{*}$ & ,685 &,- 029 & ,080 & -- & & & & & \\
\hline 9 &, $731^{*}$ & ,056 &, $277^{*}$ & ,006 &, $413^{*}$ &,$- 135^{*}$ &,- 065 &, $423^{*}$ & -- & & & & \\
\hline 10 &,$- 283^{*}$ &,$- 247^{*}$ &,$- 252^{*}$ & -,054 &,$- 191^{*}$ &,$- 206^{*}$ &,$- 181^{*}$ &,$- 203^{*}$ &,$- 114^{*}$ & -- & & & \\
\hline 11 &, $366^{*}$ &, $381^{*}$ &, $421^{*}$ & $469^{*}$ &, $490^{*}$ &,$- 092^{*}$ & ,055 &, $409^{*}$ &, $252^{*}$ &,$- 124^{*}$ & -- & & \\
\hline 12 &,$- 509^{*}$ &,- 001 &,$- 230^{*}$ &,$- 108^{*}$ &,$- 134^{*}$ & ,223* & ,037 &,$- 303^{*}$ &,$- 227^{*}$ &, $111^{*}$ &,$- 218^{*}$ & -- & \\
\hline 13 & ,088* & ,042 &, $174^{*}$ & -,019 &, $196^{*}$ &,$- 109^{*}$ & ,013 &, $227^{*}$ &, $165^{*}$ &, 025 & $155^{*}$ & ,022 & - \\
\hline
\end{tabular}

${ }^{*}$ C) Correlation is significant at the 0.05 level (2-tailed).

Note: ${ }^{1)} \mathrm{n}=420$ 
Table 4. Determinants of average perceived psychic distance $(n=600)$

\begin{tabular}{|c|c|c|c|c|c|c|}
\hline Regression no & 1 & 2 & 3 & 4 & 5 & 6 \\
\hline $\begin{array}{r}\text { Cultural distance } \\
\text { (Kogut/Singh (4)) }\end{array}$ & $\begin{array}{r}.252 * * * \\
(6.378)\end{array}$ & $\begin{array}{r}.212 * * * \\
(7.972)\end{array}$ & $\begin{array}{r}.173 * * * \\
(6.509)\end{array}$ & $\begin{array}{r}.126 * * * \\
(4.482)\end{array}$ & $\begin{array}{r}.164 * * * \\
(6.806)\end{array}$ & $\begin{array}{r}.164 * * * \\
(6.798)\end{array}$ \\
\hline $\begin{array}{l}\text { Geographical } \\
\text { distance }(\log )\end{array}$ & & $\begin{array}{c}.719 * * * \\
(27.065)\end{array}$ & $\begin{array}{l}.703 * * * \\
(27.701)\end{array}$ & $\begin{array}{r}.674 * * * \\
(25.529)\end{array}$ & $\begin{array}{r}.615 * * * \\
(27.013)\end{array}$ & $\begin{array}{c}.618^{* * * *} \\
(26.841)\end{array}$ \\
\hline $\begin{array}{r}\text { Common official } \\
\text { language(s) }\end{array}$ & & & $\begin{array}{r}-.160 * * * \\
(-5.983)\end{array}$ & $\begin{array}{r}-.159 * * * \\
(-6.044)\end{array}$ & $\begin{array}{r}-.127 * * * \\
(-5.651)\end{array}$ & $\begin{array}{r}-.126^{* * * *} \\
(-5.601)\end{array}$ \\
\hline $\begin{array}{l}\text { GDP/capita } \\
\text { difference }\end{array}$ & & & & $\begin{array}{r}.128 * * * \\
(4.531)\end{array}$ & $\begin{array}{r}.058^{*} \\
(2.357)\end{array}$ & $\begin{array}{r}.061 * \\
(2.450)\end{array}$ \\
\hline $\begin{array}{r}\text { GDP/capita } \\
\text { destination }\end{array}$ & & & & & $\begin{array}{l}-.343 * * * \\
(-15.114)\end{array}$ & $\begin{array}{l}-.341 * * * \\
(-14.990)\end{array}$ \\
\hline GDP destination & & & & & & $\begin{array}{r}-.020 \\
(-.880)\end{array}$ \\
\hline Adjusted $\mathrm{R}^{2}$ & .062 & .578 & .601 & .614 & .721 & .721 \\
\hline $\mathrm{R}^{2}$ change & $.064 * * *$ & $.516^{* * *}$ & $.024 * * *$ & $.013 * * *$ & $.106^{* * *}$ & .000 \\
\hline Standard error & 20.562 & 13.790 & 13.405 & 13.190 & 11.219 & 11.221 \\
\hline F-value & $40.682 * *$ & $411.492 * * *$ & $302.253 * * *$ & $239.248 * * *$ & $310.242 * * *$ & $252.566^{* * *}$ \\
\hline
\end{tabular}

Standardized regression coefficients. t-values in parenthesis. two-tailed tests

*. $\mathrm{p}<0.05 ;{ }^{* *} \mathrm{p}<0.01 ; * * * \mathrm{p}<0.001$ 
Table 5. The influence of Hofstede's cultural dimensions on perceived psychic distance.

\begin{tabular}{|c|c|c|c|c|}
\hline Regression no & $\begin{array}{c}1 \\
\text { (from Table 4) }\end{array}$ & 7 & 8 & 9 \\
\hline $\mathrm{n}$ & 600 & 600 & 420 & 420 \\
\hline Kogut/Singh (4) & $\begin{array}{r}0.252 * * * \\
(6.378)\end{array}$ & & & \\
\hline Kogut/Singh (5) & & & $\begin{array}{r}0.478 * * * \\
(11.141)\end{array}$ & \\
\hline PDI difference & & $\begin{array}{r}0.109 * * \\
(2.713)\end{array}$ & & $\begin{array}{r}0.067 \\
(1.548)\end{array}$ \\
\hline IDV difference & & $\begin{array}{r}0.387 * * * \\
(9.884)\end{array}$ & & $\begin{array}{r}0.306^{* * * *} \\
(5.580)\end{array}$ \\
\hline MAS difference & & $\begin{array}{r}-0.000 \\
(-0.020)\end{array}$ & & $\begin{array}{r}0.029 \\
(0.710)\end{array}$ \\
\hline UAI difference & & $\begin{array}{r}-0.017 \\
(-0.430)\end{array}$ & & $\begin{array}{r}-0.012 \\
(-0.293)\end{array}$ \\
\hline LTO difference & & & & $\begin{array}{r}0.325^{* * *} \\
(5.845)\end{array}$ \\
\hline Adjusted $\mathrm{R}^{2}$ & 0.062 & 0.176 & 0.227 & 0.356 \\
\hline Standard error & 20.562 & 19.277 & 19.400 & 17.705 \\
\hline F-value & $40.682 * * *$ & $32.910 * * *$ & $124.122 * * *$ & $47.375^{* * *}$ \\
\hline
\end{tabular}

Standardized coefficients, t-values in parenthesis, two-tailed tests

${ }^{\dagger} \mathrm{p}<0.1 ; *$. $\mathrm{p}<0.05 ; * * \mathrm{p}<0.01 ; * * * \mathrm{p}<0.001$ 
Figure 1. Relationship between cultural distance from the Netherlands and the rank correlation between perceived psychic distance and cultural distance according to the Kogut/Singh index.

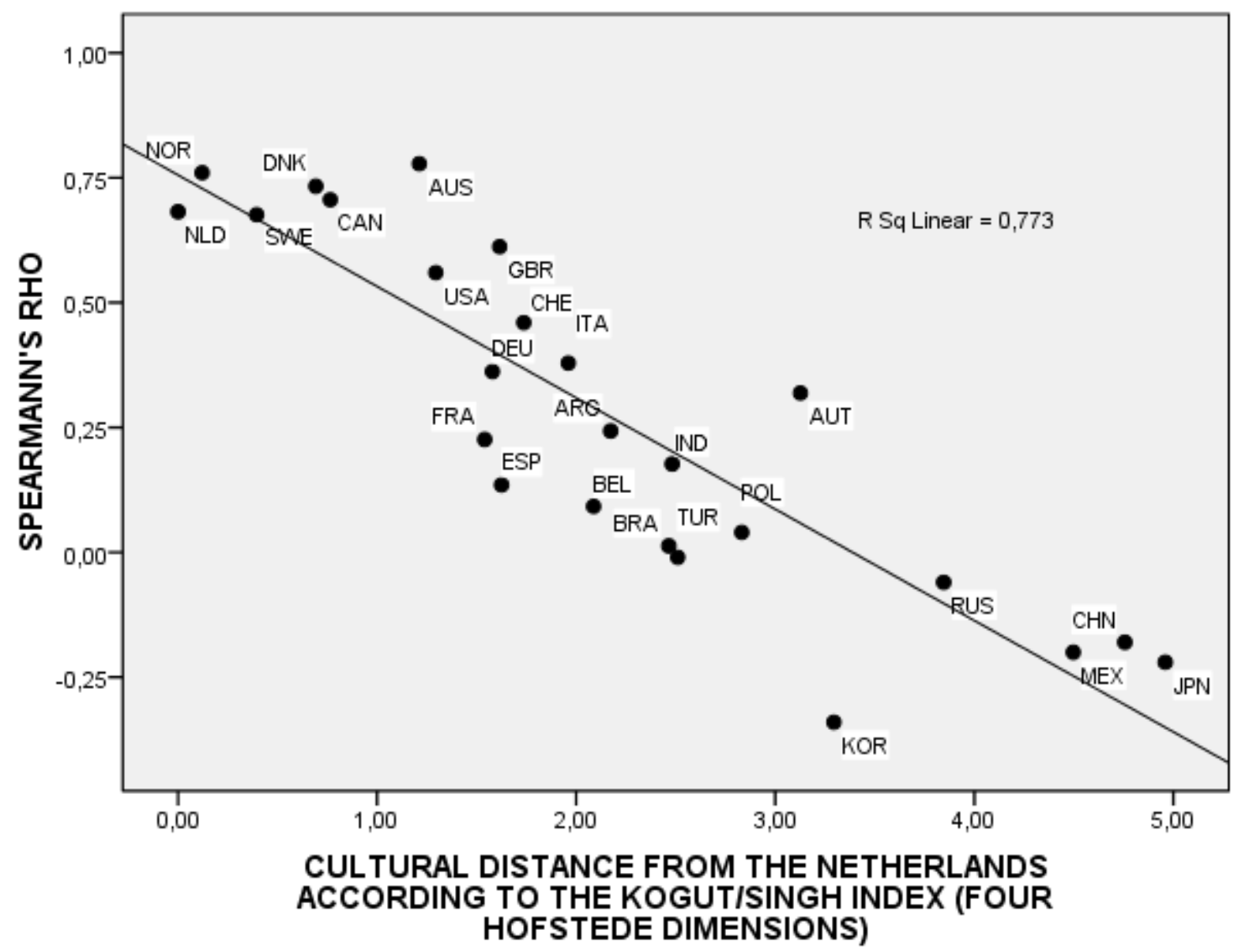

